\title{
Identification of yeasts associated with the fermented fish, adjuevan, of Ivory Coast by using the molecular technique of PCR-denaturing gradient gel electrophoresis (DGGE)
}

\author{
Kouakou Amenan Clementine ${ }^{1,2 \star}$, Cisse Mohamed ${ }^{1}$, Kossonou Epiphane ${ }^{2}$, \\ Brou kouakou David ${ }^{2}$, Marcellin Koffi Dje ${ }^{2}$ and Didier Montet ${ }^{1}$
}

${ }^{1}$ Centre de Coopération Internationale en Recherche Agronomique pour le Développement, CIRAD, UMR Qualisud, TA 95B/16, 34398 Montpellier Cedex 5, France.

${ }^{2}$ University of Abobo-Adjame Laboratory of Microbiology and Molecular Biology, Unit Training and Research in Food Science and Technology (UFR-STA), 02 BP 801 Abidjan 02, Ivory Coast.

Accepted 27 December, 2011

\begin{abstract}
Diversity of yeasts was investigated by using a molecular technique employing variable regions of $26 \mathrm{~S}$ rDNA profiles generated by PCR-denaturing gradient gel electrophoresis (DGGE) in the salted and fermented traditional fish named "adjuevan". This fermented fish was produced in lvory Coast at ambient temperature $\left(28\right.$ to $\left.30^{\circ} \mathrm{C}\right)$ following two traditional fermentation methods. Fermentation according to Method 1 was made in jars covered with plastics and stones for 5 days then dried for three days on racks or nets. For Method 2, fermentation and fish drying took place on racks or nets simultaneously for at least 10 days. PCR-DGGE and DNA sequencing was used to compare yeasts from both methods of production, and they were identified as Kluyveromyces marxianus, Hansenula anomala, Saccharomyces cerevisiae, Candida tropicalis, Candida zeylanoides, Pichia fermentans, Debaromyces hansenii, Hanseniaspora osmophilic, and Rhodotorula glutinis which had not been previously described in fermented fish. Yeast diversity was higher for Method 1, while the predominance strains of Debaromyces sp. and Candida sp. with Kluyveromyces sp. were higher for Method 2. This study showed the presence of yeast species and their participation in the fermentation of adjuevan. D. Hansenii and $K$. marxianus could be used as starter cultures for the standardisation of the fermented fish, adjuevan.
\end{abstract}

Key words: Adjuevan, yeasts, microbial community, PCR-denaturing gradient gel electrophoresis (DGGE).

\section{INTRODUCTION}

Aquatic microorganisms are known to be closely associated with the physiological status of fish (Al-Harbi and Uddin, 2003; Leesing, 2005). Yeasts are ubiquitous microorganisms, which can grow in various environments where organic substrates are available. Their presence has been noted in fish guts for some time in wild as well as farmed animals, but this natural occurrence has been generally considered incidental. They are capable of

\footnotetext{
${ }^{*}$ Corresponding author. E-mail: kclementine24@yahoo.fr
}

growing and multiplying on complex substrates with high amounts of sugar, salt, low $\mathrm{pH}$, low temperature and low water activity (aw) (Jakobsen and Narvhus, 1996; Lopandic et al., 2006). Yeast growth may play either a beneficial or a detrimental role on food products (Lopandic et al., 2006). Yeasts have also been increasingly considered as important agents in the maturation process of some cheeses. First, by metabolizing lactic acid, they facilitate the implantation of an acidosensitive bacterial biota. Second, by their proteolytic and lipolytic activities, they generate the precursors of aromas (free amino acids and fatty acids), and that may 
contribute significantly to the final flavour (Romano et al., 1996). In France, Spain, and Italy, fermented sausages (the sensory properties of the products) are also influenced by the development of the surface flora, consisting of moulds and yeasts (Lücke, 2000). Many types of yeast can utilize lactic acid, leading to an increase in the $\mathrm{pH}$, and this encourages the growth of secondary $\mathrm{pH}$-sensitive microorganism. Bacteria growth may be stimulated by the amino acids and vitamins produced by yeasts (Fleet, 1990). Yeasts may also play an important role as inhibitors of undesired bacteria, like spore-forming bacteria of the genus Clostridium such as Clostridium butyricum and Clostridium tyrobutyricum (Fatichenti et al., 1983). Moreover, a variety of yeast species including Zygosaccharomyces rouxii, Debaryomyces and Hansenula have been also reported to be associated with the ecology of salted and traditionally fermented fish from Thailand and Ghana (Paludan-Muller et al., 2002; Sanni et al., 2002). Food associated yeasts could also be an underestimated source of infections and adverse health responses. Furthermore, yeast species such as Candida zeylanoides, found in humans, soil, meat, fish, and water had been reported as an emerging pathogen, especially on immune compromised patients causing fungemia and arthritis (Deak and Beuchat, 1996; Dorko et al., 2000). Development of analytic methods, identification, characterization and classification of yeast isolates had become essential for processing, preservation, conservation and food safety. Over recent years, cultureindependent methods based on molecular biology techniques have been developed to study microbial such as denaturing gradient gel electrophoresis (DGGE). This method has been used to investigate yeast population dynamics in milk and fermented products, including wine, fermented cassava (manioc), maize dough and coffee beans (Cocolin et al., 2002; Masoud et al., 2004; Prakitchaiwattana et al., 2004). El Sheikha et al. (2009) used PCR-DGGE to trace physalis fruits from diverse geographical origin by analysing the ecology of yeasts using the variable region of $26 \mathrm{~S}$ rDNA. rDNA $26 \mathrm{~S}$ is relatively easy to isolate for the abundance in cells, sequence is long enough to make comparisons statistically consistent, particularly suitable to study the relationship between the primary sequence and secondary structure because their structures are much more variable than those of the small subunit and has a well preserved structure (Hancock et al., 1988; Kurtzman and Robnett, 1998). Other investigations on the occurrence of yeasts in agricultural products have been carried out to compare traditional microbiological methods and culture-independent methodologies (Masoud et al., 2004; Nielsen et al., 2007). PCR-DGGE was successfully used for the investigation of the microbial ecology of sourdoughs, sausages (Rantsiou and Cocolin, 2006; Zhang et al., 2011). However, no investigation was focused on yeast diversity of this traditional fermented fish, despite the important place of the adjuevan in Ivorian people's food history.

This study aims to assess the presence and diversity of dominant yeasts flora according to two fermentation processes of adjuevan from Ivory Coast by using the DNA directly extracted from the fermented fish and analysed by PCR-DGGE which target the yeast 26s rDNA, and then identifying it after sequencing.

\section{MATERIALS AND METHODS}

\section{Production and sampling of the fermented fish adjuevan}

The fermented fish of Ivory Coast was produced according to two traditional methods, "Method 1 and Method 2", prepared at ambient temperature $\left(28\right.$ to $\left.30^{\circ} \mathrm{C}\right)$ by women along continental rivers or the sea. According to Method 1, fish was first kept in a jar or a bowl without water for $48 \mathrm{~h}$, and then it was cleaned and dry-salted with sea salt. After that, it was fermented for 5 days in jars covered with plastics or platelets on which stones were deposited. After fermentation, the fishes were sun dried on racks or nets for 3 days before being marketed. For Method 2, the fish was first kept for 24 $\mathrm{h}$ without water, and then cleaned, opened along the spine, and followed by dry salting. Fermentation took place during drying on racks or nets for at least 10 days (Figure 1).

Four producers were selected at the production sites of Vridi and Assinie in South Ivory Coast, according to several criteria including the amount of production, regularity in production, strong customer service, ease of access to the site and the simultaneous use of two methods of fermentation at weekly intervals. Two producers were selected per site of production. The first producer named PA and the second producer named PD were from the site of Abidjan, whereas the first producers named PB and PC were from the site of Assinie. Samples PA1 and PA2 were successively produced following Method 1 by producer PA; samples named PB1 and PB2 were successively produced by the same Method 1 by producer PB. Same numeration was applied for samples PC1 and PC2. Likewise, PD1 and PD2 were produced by Method 2 by producers PC and PD. A total of 48 samples of $2 \mathrm{~kg}$ per sample of adjuevan produced with sea fish (Galeoides decadactylus) were collected aseptically after drying at a weekly interval for the two productions. Samples were collected in triplicate then put in sterile plastic bags aseptically for different physicochemical and microbiological analysis.

\section{Chemical analysis}

In this study, the following physicochemical analyses: $\mathrm{pH}, \mathrm{Aw}$, salt content, water content and titrable acidity were performed. Sodium content was determined by a chloride analyser (Corning Chloride analyser 926) after cold extraction in $0.3 \mathrm{~N}$ nitric acid (Bohuon, 1995). Water activity was determined using a water activity meter (AQUA LAB 4TE Decagon Devices fashion). Water content was determined on $5 \mathrm{~g}$ of sample by drying in an oven (Firlabo) at $103 \pm$ $2^{\circ} \mathrm{C}$ for $24 \mathrm{~h}$ (Audigié et al., 1980).

$\mathrm{pH}$ and titrable acidity were determined by an automatic titrimeter (TitroLine easy Schott 96) on $5 \mathrm{~g}$ of fermented fish dissolved in 50 $\mathrm{ml}$ distilled water after homogenization during $30 \mathrm{~min}$, then titrated by $0.05 \mathrm{~N} \mathrm{NaOH}$.

\section{Microbiological analysis}

\section{Enumeration of yeasts}

Ten grams of fermented fish adjuevan were aseptically weighed 


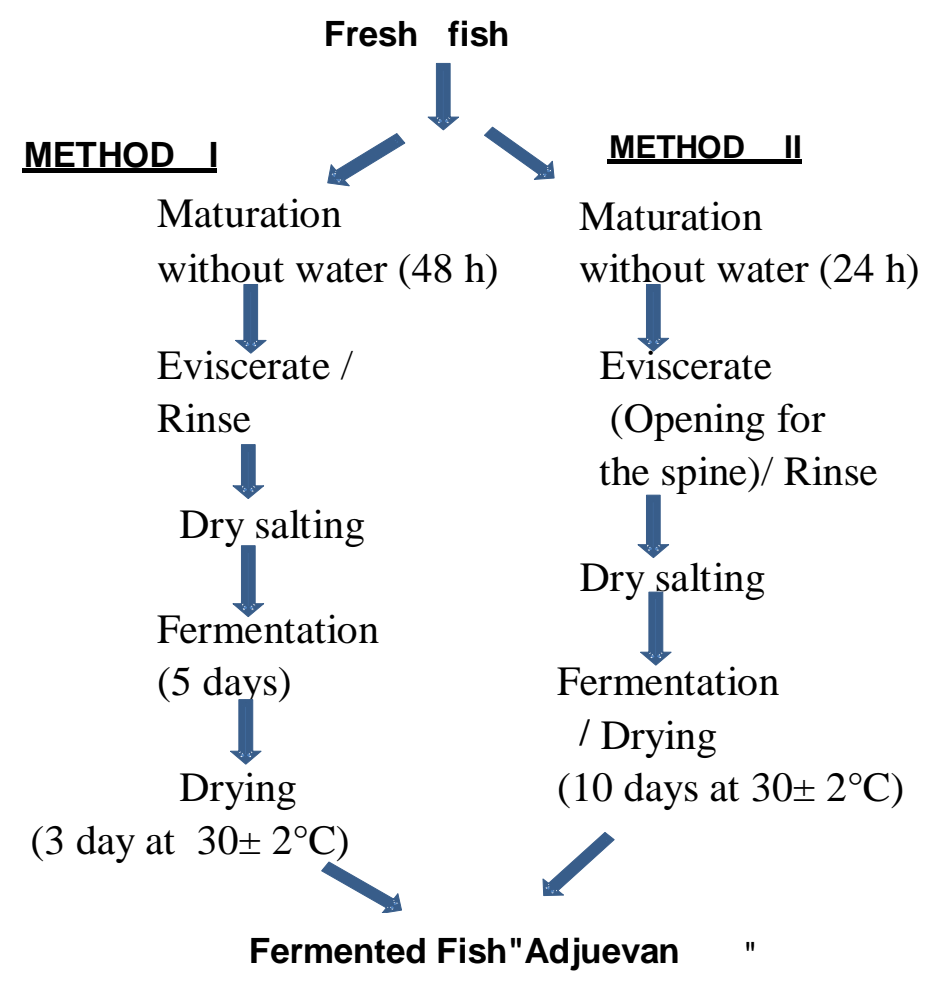

Figure 1. Methods of production of fermented fish "adjuevan".

and transferred into sterile $50 \mathrm{ml}$ bottles containing $25 \mathrm{ml}$ peptone physiological saline at $0.8 \% \mathrm{NaCl}$ (Merck, Germany), $0.1 \%$ neutral peptone (Oxoid, Basingstoke, UK). Then, bottles were vortexed for $15 \mathrm{~min}$ and appropriate serial dilutions $\left(10^{-1}\right.$ to $\left.10^{-6}\right)$ were plated in duplicate on malt extract agar (MEA) (Oxoid) containing $0.1 \%$ oxytetracycline (Sigma-Aldrich Co., USA). The MEA plates were incubated at $25^{\circ} \mathrm{C}$ for 4 days. After the incubation, a differential count based on colony color was made.

\section{DNA extraction from yeast}

DNA extraction from yeast was done according to El Sheikha et al. (2009) after the modification of the methods used by Masoudet et al. (2004) and Chumillas Ros et al. (2007). $8 \mathrm{~g}$ of fermented fish samples taken from skin, abdomen and head were homogenized by vortex for $30 \mathrm{~min}$ (Vortex Genie 2 SI-A256, USA) after addition of $16 \mathrm{ml}$ of sterile peptone water (pH 7.0, Dickinson, France). Two Eppendorf tubes of $2 \mathrm{ml}$ containing the homogenate were vortexed for $10 \mathrm{~min}$ and centrifuged at $12000 \mathrm{~g}$ for $15 \mathrm{~min}$, then the supernatant was discarded. The cell pellet was resuspended in $300 \mu \mathrm{l}$ of breaking buffer [2\% Triton X-100 (Prolabo, France), 1\% SDS (sodium dodecyl sulphate; Sigma, France), $100 \mathrm{mM} \mathrm{NaCl}$ (Sigma), $10 \mathrm{mM}$ Tris, pH 8.0, $1 \mathrm{mM}$ EDTA, pH 8.0 (Promega, France)]. 100 $\mu \mathrm{l}$ TE [10 mM Tris-HCl; $1 \mathrm{mM}$ EDTA; pH 8.0 (Promega)], $100 \mu \mathrm{l}$ lysozyme solution (25 mg/ml, Eurobio, France), and $100 \mu \mathrm{l}$ proteinase $\mathrm{K}$ solution (20 mg/ml, Eurobio, France)] were added and the mixture was incubated at $42^{\circ} \mathrm{C}$ for $20 \mathrm{~min}$. Then $50 \mu \mathrm{l}$ of $20 \%$ SDS were added to each tube, and then incubated at $42^{\circ} \mathrm{C}$ for 10 min. $400 \mu \mathrm{l}$ MATAB (mixed alkyltrimethyl ammonium bromide; Sigma) were added to each tube, and then incubated at $65^{\circ} \mathrm{C}$ for 10 min. The lysates were then purified twice by repeated extraction with $700 \mu \mathrm{l}$ phenol/chloroform/isoamyl alcohol (25/24/1; Carlo Erba, France), and the tubes were vortexed for $1 \mathrm{~min}$ and centrifuged at
$12000 \times g$ for $15 \mathrm{~min}$. The aqueous layer was transferred to an Eppendorf vial and the residual phenol was removed by extraction with $600 \mu \mathrm{l}$ chloroform/isoamyl alcohol (24/1), and centrifuged for $15 \mathrm{~min}$ at $12000 \times \mathrm{g}$. The aqueous phase was collected and the DNA was stabilized with $30 \mu \mathrm{l}$ sodium acetate $(3 \mathrm{M}, \mathrm{pH} 5)$, followed by precipitation by adding an equal volume of ice-cold isopropanol, and stored at $-20^{\circ} \mathrm{C}$ for $12 \mathrm{~h}$ (overnight). After centrifugation at $12000 \times g$ for $15 \mathrm{~min}$, the supernatant was eliminated, DNA pellets were washed with $500 \mu \mathrm{l} 70 \%$ ethanol, and the tubes were centrifuged at $12000 \times g$ for $15 \mathrm{~min}$. The ethanol was then discarded and the pellets were air-dried at room temperature for $3 \mathrm{~h}$. Finally, the DNA was resuspended in $50 \mu \mathrm{l}$ of ultrapure water and stored at $-20^{\circ} \mathrm{C}$ until analysis.

\section{PCR-denaturing gradient gel electrophoresis (DGGE) analysis}

A fragment of the D1/D2 region of the 26S rRNA gene was amplified using eukaryotic universal primers: forward, NL1GC (5'CGC CCG CCG CGC GCG GCG GGC GGG GCG GGG GCC ATA TCA ATA AGC GGA GGA AAA G-3'; Sigma); reverse, LS2 (5'-ATT CCC AAA CAA CTC GAC TC-3'; Sigma), amplifying a 250 bp fragment (Kurtzman and Robnett, 1998; Cocolin et al., 2000). A 30 bp GC clamp (Sigma) was added to the forward primer (GC clamp is underlined). PCR amplification was performed in a final volume of $50 \mu \mathrm{l}$ according to the protocols described by El Sheikha et al. (2009). Aliquots $(5 \mu \mathrm{l})$ of PCR products were analysed first by conventional electrophoresis in $2 \% \mathrm{w} / \mathrm{v}$ agarose gel with TAE $1 \times$ buffer $(40 \mathrm{mM}$ Tris- $\mathrm{HCl}, \mathrm{pH} 7.4,20 \mathrm{mM}$ sodium acetate, $1.0 \mathrm{mM}$ $\mathrm{Na}_{2}-$ EDTA), stained with ethidium bromide (Promega) $50 \mu \mathrm{g} / \mathrm{ml}$ in TAE $1 \times$ and quantified by using a standard (DNA mass ladder 100 bp; Promega). PCR products were analysed by DGGE, by using a Bio-Rad code universal mutation detection system (Bio-Rad, USA), using first the procedure described by Muyzer et al. (1993) 
Table 1. Microbial and physicochemical characteristics of fermented fish "adjuevan" produced by two methods of fermentation in Ivory Coast.

\begin{tabular}{|c|c|c|c|c|c|c|c|}
\hline Adjuevan & Sample & $\mathrm{pH}$ & $\begin{array}{c}\text { Titrable acidity } \\
(\%)\end{array}$ & $\begin{array}{l}\text { Salt content } \\
(\% \mathrm{NaCl})\end{array}$ & Water activity & $\begin{array}{c}\text { Water content } \\
(\%)\end{array}$ & $\begin{array}{c}\text { Yeasts } \\
(\log \text { CFU/g) }\end{array}$ \\
\hline \multirow{4}{*}{$\begin{array}{l}\text { Method } 1 \\
(\mathrm{n}=24)\end{array}$} & PA1 & $6.5 \pm 0.3^{a}$ & $11.8 \pm 0.5^{\mathrm{a}}$ & $5.1 \pm 0.01^{\mathrm{b}}$ & $0.89 \pm 0.01^{a}$ & $55.8 \pm 0.4^{\mathrm{b}}$ & $4.3 \pm 0.1^{\mathrm{a}}$ \\
\hline & PA2 & $5.6 \pm 0.2^{\mathrm{a}}$ & $16.5 \pm 0.4^{b}$ & $2.2 \pm 0.3^{\mathrm{a}}$ & $0.96 \pm 0.05^{\mathrm{a}}$ & $66.1 \pm 0.7^{a}$ & $6.3 \pm 0.4^{b}$ \\
\hline & PB1 & $6.4 \pm 0.1^{a}$ & $14.4 \pm 0.3^{a}$ & $4.2 \pm 0.02^{\mathrm{ab}}$ & $0.93 \pm 0.1^{\mathrm{a}}$ & $66.4 \pm 0.2^{\mathrm{a}}$ & $4.4 \pm 0.02^{\mathrm{a}}$ \\
\hline & PB2 & $6.5 \pm 0.4^{\mathrm{a}}$ & $13.1 \pm 0.5^{\mathrm{a}}$ & $3.1 \pm 0.4^{\mathrm{a}}$ & $0.96 \pm 0.6^{a}$ & $62.2 \pm 0.01^{\mathrm{a}}$ & $5.1 \pm 0.5^{\mathrm{a}}$ \\
\hline \multirow{4}{*}{$\begin{array}{l}\text { Method } 2 \\
(n=24)\end{array}$} & $\mathrm{PC} 1$ & $6.6 \pm 0.03^{a}$ & $9.5 \pm 0.2^{\mathrm{a}}$ & $7.5 \pm 0.3^{c}$ & $0.83 \pm 0.04^{\mathrm{a}}$ & $27.6 \pm 0.1^{d}$ & $2.8 \pm 0.3^{\mathrm{a}}$ \\
\hline & PC2 & $6.7 \pm 0.1^{\mathrm{a}}$ & $9.1 \pm 0.1^{\mathrm{a}}$ & $10.3 \pm 0.5^{c}$ & $0.75 \pm 0.02^{b}$ & $38.6 \pm 0.05^{c}$ & $4.4 \pm 0.03^{\mathrm{a}}$ \\
\hline & PD1 & $6.6 \pm 0.6^{\mathrm{a}}$ & $10.3 \pm 0.2^{\mathrm{a}}$ & $5.4 \pm 0.4^{b}$ & $0.85 \pm 0.1^{\mathrm{a}}$ & $42.9 \pm 0.3^{c}$ & $3.1 \pm 0.4^{\mathrm{a}}$ \\
\hline & PD2 & $6.5 \pm 0.1^{a}$ & $8.0 \pm 0.6^{\mathrm{a}}$ & $5.2 \pm 0.03^{b}$ & $0.87 \pm 0.05^{\mathrm{a}}$ & $46.2 \pm 0.3^{c}$ & $2.9 \pm 0.6^{a}$ \\
\hline
\end{tabular}

Values are expressed as means \pm standard deviation for three independent trials; Means values with the same letter in a line for each parameter are not significantly different $(\mathrm{P}>0.05)$. PA1; PA2 and PD1; PD2: Two successive productions carried out by a local producer at Abidjan-Vridi following respectively method 1 and method 2. PB1; PB2 and PC1; PC2: Two successive productions carried out by a local producer at Assinie following respectively Method 1 and Method 2.

and improved by Leesing (2005). Samples containing approximately equal amounts of PCR amplicons were loaded into $8 \% \mathrm{w} / \mathrm{v}$ polyacrylamide gels (acrylamide: $N, N$ - methylene bisacrylamide, $37.5 / 1$; Promega) in $1 \times$ TAE buffer $(40 \mathrm{mM}$ Tris- $\mathrm{HCl}, \mathrm{pH} 7.4,20$ $\mathrm{mM}$ sodium acetate, $1.0 \mathrm{mM} \mathrm{Na} \mathrm{Na}_{2}$-EDTA). All electrophoresis experiments were performed at $60^{\circ} \mathrm{C}$, using a denaturing gradient in the range of 30 to $60 \%$ (100\% corresponded to $7 \mathrm{M}$ urea and $40 \% \mathrm{v} / \mathrm{v}$ formamide; Promega). The gels were electrophoresed at $20 \mathrm{~V}$ for $10 \mathrm{~min}$ and then at $80 \mathrm{~V}$ for $12 \mathrm{~h}$. After electrophoresis, the gels were stained for $30 \mathrm{~min}$ with ethidium bromide and rinsed for $10 \mathrm{~min}$ in distilled water and then photographed on a UV transilluminator with the Gel Smart 7.3 system (Clara Vision, Les Ulis, France).

\section{Statistical analysis}

Chemical analysis results were statistically evaluated by one way analysis of variance (ANOVA) and Bonferroni test (Dunn) at $p<0.05$ with the software Statistica, 99 Edition.

\section{Imaging and statistical analysis}

Individual lanes of the gel images were straightened and aligned using Image Quant TL software v. 2003 (Amersham Biosciences, USA). Banding patterns were standardized with two reference patterns included in all gels, Wickerhamomyces anomalus DNA and Komagataella pastoris DNA. This software permitted the identification of bands' relative positions compared with standard patterns. In DGGE analysis, the generated banding pattern is considered as an image of the major yeasts in the populations. An individual discrete band refers to a unique 'sequence type' or phylotype (Muyzer et al., 1995; Van Hannen et al., 1999). This was confirmed by Kowalchuk et al. (1997) who showed that co-migrating bands generally corresponded to identical sequences. The DGGE fingerprints were manually scored by the presence and absence of co-migrating bands, independent of intensity. Pairwise community similarities were quantified using the Dice similarity coefficient (SD) (Heyndrickx et al., 1996):

$$
S D=2 \mathrm{Nc} / \mathrm{Na}+\mathrm{Mb}(1)
$$

where $\mathrm{Na}$ represents the number of bands detected in sample $\mathrm{A}$, $\mathrm{Nb}$ the number of bands in sample $\mathrm{B}$, and $\mathrm{Nc}$ the number of bands common to both samples. The similarity index was expressed within a range of 0 (completely dissimilar) to 100 (perfect similarity). Significant differences of yeast communities of samples were determined by factorial correspondence analysis, using the first two variances that described most of the variation in the data set.

\section{Purification and sequencing}

Bands were cut from the gel and the amplicons were purified using the Wizard PCR purification kit (Preps DNA Purification System, Promega, France) followed by a new PCR but with primers without GC clamp. The PCR products were then sent to GATC Biotech (Germany) where they were submitted to a second DNA purification before sequencing. Sequence of $26 \mathrm{~S}$ rDNA comparisons were performed using the basic local alignment search tool (BLAST) in GenBank (www.ncbi.nlm. nih.gov/blast) after editing and trimming the sequences by BioEdit sequence alignment editor, version 7.0.0. The yeast isolates were identified based on a 99 to $100 \%$ similarity criterion.

\section{RESULTS AND DISCUSSION}

\section{Chemical analysis}

The results of the chemical analysis are shown in Table 1. Sample from Method 1 gave a final $\mathrm{pH}$ between 5.6 and 6.5, and the samples from Method 2 had $\mathrm{pH}$ from 6.5 and 6.7 showing that, irrespective of the method of production used, the $\mathrm{pH}$ varied very little, and was generally above 6 . These results were in conformity with those of different works done on fermented fish (Sanni et al., 2002; Anihouvi et al., 2007) which have also shown that the $\mathrm{pH}$ of fermented fish was above 6 . Aw and salt content of samples of Method 1 varied respectively between 0.96 and 0.89 , and 2.1 and $5.1 \%$. The titrable acidity varied from 11.8 to $16.5 \%$. The samples produced by Method 2 presented an Aw and a salt content respectively between 0.87 and 0.75 , and 5.5 and $10.2 \%$, then a lower titrable acidity from 8.04 to $10.3 \%$. In addition, the samples of Method 1 were wetter 


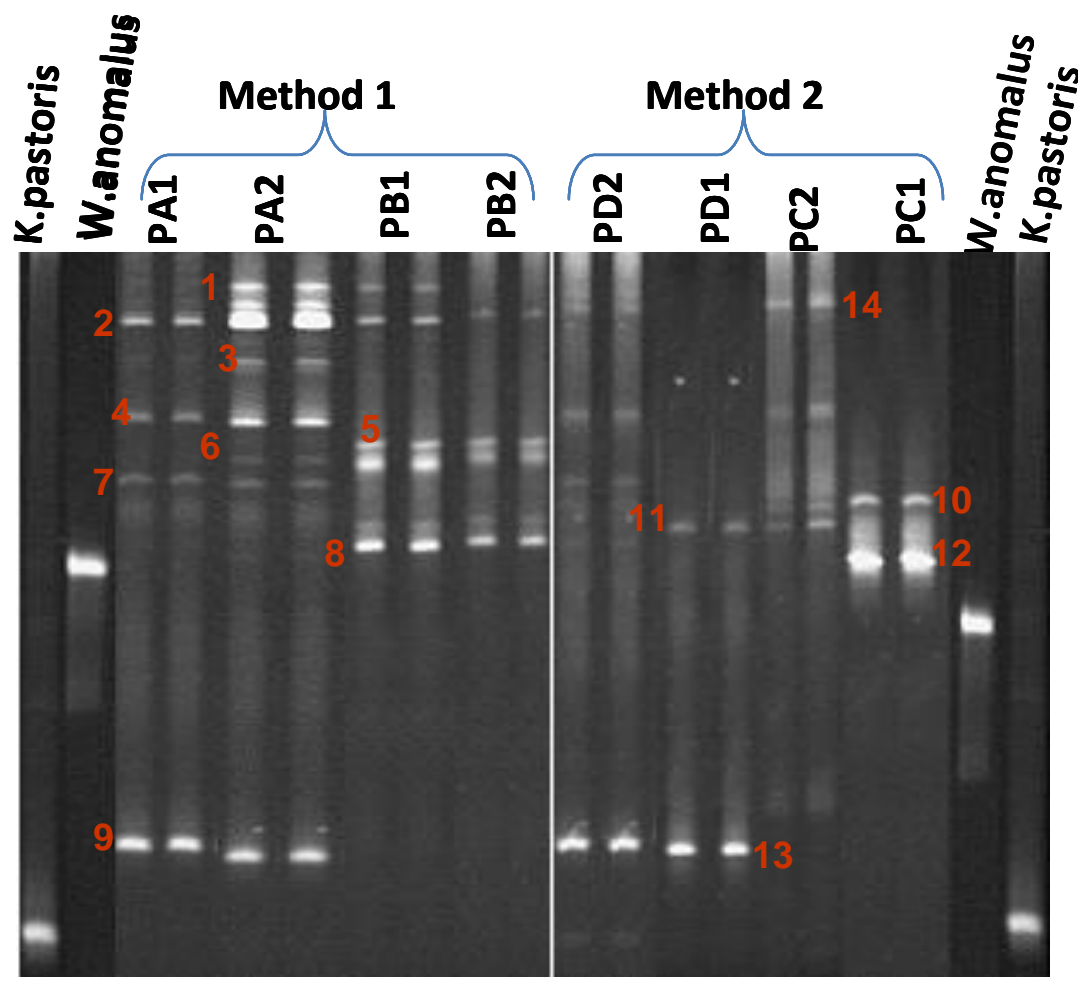

Figure 2. DGGE profiles of the bacterial community from DNA directly extracted from adjuevan produced with two processing methods. Bands indicated by numbers were excised and, after re-amplification, subjected to sequencing. 1-14. Debaromyces sp; 2. Debaromyces hansenii; 3. Hansenula anomala; 4. Saccharomyces cerevisiae; 5. Candida tropicalis; 6. Candida zeylanoides; 7. Pichia fermentans; 8. Kluyveromyces marxianus; 9-13. Hanseniaspora osmophila; 10-11. Kluyveromyces sp; 12. Rhodotorula glutinis. PA1, PA2 and PD1, PD2: Two successive productions carried out by a local producer at Abidjan-Vridi following respectively Method 1 and Method 2. PB1, PB2 and PC1, PC2: Two successive productions carried out by a local producer at Assinie following respectively Method 1 and Method 2.

(above 55\%) than those of Method 2 with water content under $46 \%$. Our results showed that the samples from Method 1 can be more favourable for microbial flora growth because of their lower salt content, elevated Aw, and a $\mathrm{pH}$ near neutral with higher water content. Whatever the method of production used, or the producers for the same fermentation conditions (equipment, room temperature, and fermentation time), the salt content varied from one production to another. This variation was due to the addition of salt with the approval of the producers. These results were in agreement with those of Anihouvi et al. (2005) who showed that salt was added to the fish at the approval of the producers on fermented fish of Benin. All the characteristics varied from one production to another, from one producer system to another, and also according to the method of production and the amount of salt added. The variation of titrable acidity, Aw and salt content were significant with $p \leq 0.05$ according to the amount of salt added, the producer, and the method of fermentation used.

\section{Microbiological analysis}

The load of yeast values in samples from Method 1 was 4.3 to $6.3 \mathrm{cfu} / \mathrm{g}$, then those from samples of the second method were 2.8 to $4.4 \mathrm{cfu} / \mathrm{g}$ (Table 1). There was no significant variation of yeast load according to both methods. Yeasts had not been detected during any time of lanhouin fermentation (Anihouvi et al., 2007). The presence of yeasts in adjuevan samples could be explained by a contamination of fish of the non-sterile fermenting material and the favorable physicochemical characteristics of the fermented fish, adjuevan, for microbe's growth.

PCR-DGGE patterns of samples for Method 1 revealed 4 to 8 bands of yeast DNA and the profiles of samples of Method 2 had only 2 to 4 bands of yeast DNA (Figure 2). This implies that there were quantitatively more bands of yeast in Method 1. Samples of Method 1 produced successively by the same producer had almost common bands. Samples PA1 and PA2 successively produced at intervals of one week by producer PA in the same jars 
had several common DNA bands, such as samples for PB1 and PB2 by producer PB. However, DGGE profiles of the samples from Method 2 were very different from each other, as can be seen for samples PC1 and PC2 produced successively at intervals of one week by producer PC, and samples PD1 and PD2 also produced successively at intervals of one week by producer PD. These results suggested that the yeast of the fish adjuevan fermented by Method 1 can be influenced by the microorganisms present in the fermentation equipment and the process used. In addition, the influence of salt was also seen; as the salt content increased, additional less bands were found for the same method of production and equipment used. We observed that sample PA2 had a lower salt content that conducted to 2 more bands (6 bands of DNA) than sample PA1 (4 bands). The same was observed for samples PB1 that had one more band of DNA than PB2. PC2 had also two more bands of DNA than PC1. The same observation was made for sample PD1 that had 3 bands of DNA, with a higher salt content, than PD2. According to the origins of the fishes used in this work, we observed that samples PA1 and PA2 and samples PD1 and PD2 produced by different producers with fish from the same origin have two common bands (Bands 2 and 13). Similarly, samples PB1-PB2 and PC1-PC2 produced with fish from the same origin by two different producers (PB and PC) had only one common band (band 14). These results suggested that some microorganisms present in the traditional fermented fish could come from the environment of the raw material. The results of this study are in agreement with those of several authors including Larrouture et al. (2000), Mauriello et al. (2004), and Rantsiou et al. (2005) who suggested that microorganisms present in traditional sausages came from the raw materials used or from the environment.

A total of 86 bands of yeasts DNA was obtained, from which 69 representatives (48 bands for Method 1, and 21 bands for Method 2) were sequenced and identified. The yeasts belonged to 8 genera: Debaryomyces, Kluyveromyces, Hansenula, Saccharomyces, Candida, Pichia, Hanseniaspora, and Rhodotorula (Figure 2). These genera of yeast were also found on the skin or in the intestines of fresh fish by Andlid et al. (1995), and Gatesoupe (2007). Their ability to grow on complex substrates with high amounts of sugar, salt, low $\mathrm{pH}$, low temperature, and low water activity (aw) was also shown (Jakobsen and Narvhus, 1996; Lopandic et al., 2006). The numbers and types of species isolated varied with the method of production. So according to Method 1, Kluyveromyces sp. and Debaromyces sp. were obtained. The dominant species for Method 1 were $D$. hansenii and Candida sp. with respective percentages of 41.6 and $22.9 \%$ for all strains. This might be the result of the combined effect of salt concentration, anaerobic process, $\mathrm{pH}$ around 6, Aw around 0.9 of samples, and the previously reported condition which was favourable for the growth of this yeast by Betts et al. (1999). Moreover $D$. hansenii has been reported to have the ability to grow at extremely high salt and nitrite concen-trations, and low Aw as compared to C. zeylanoides (Viljoen and Greyling, 1995; Asefa et al., 2009). In cheeses with high salt content, $D$. hansenii was predominant and has been recognised to accelerate the lipolysis and proteolysis activities that are thus important for the sensory qualities of cheese and dry-cured meat products (Pereira-Dias et al., 2000; Martin et al., 2006; Patrignani et al., 2007; Jacques and Casaregola, 2008; Andrade et al., 2009). For Method 2, Kluyveromyces sp. and $\mathrm{H}$. osmophila were the dominant species being 47.7 and $28.6 \%$, respectively. Kluyveromyces species as $K$. marxianus was reported to be an alternative producer of animalsource of carboxypeptidase enzyme that is important in industries (Ramirez-Zavala et al., 2004).

This finding showed that $D$. hansenii and $K$. marxianus can have a positive contribution for the development of sensory qualities of fermented fish as it was observed in cheeses and dry-cured meat products (Bolumar et al., 2006; Martin et al., 2006; Fleet, 2007; Andrade et al., 2009 ) in addition to the hygienic quality of adjuevan. $C$. tropicalis was founded in the samples produced by Method 1 and Rhodotorula glutinis was present only in one sample produced by Method 2. Loveness et al. (2007) had reported that Rhodotorula $s p$. and $C$. tropicalis were relatively frequent in both marine and freshwater fish. Vázquez-Juárez et al. (1993) showed that $R$. rubra, $R$. glutinis, and Candida zeylanoides strains isolated from flatfish can adhere to several substrates. However, C. tropicalis has been shown to be pathogen for humans and it has a greater potential of causing disease in immunocompromised humans (Pfaller et al., 1987). So the presence of $R$. glutinis, Candida tropicalis, and $H$. osmophila in the yeasts can be seen from the original raw fish, also linked to a contamination by the environment, from the material of fermentation or from the producer.

The identification of $S$. cerevisiae from adjuevan is unusual because they are not frequently associated with salted fermented fish products. This absence may be due to the low content of sugar in the fish flesh. Nonetheless, Izgü et al. (2004) had reported that $S$. cerevisiae can secrete a killer toxin to inhibit the growth of the contaminant yeast $C$. tropicalis at a temperature of 20 to $30^{\circ} \mathrm{C}$. So, S. Cerevisiae can have a positive contribution for the hygienic quality of adjuevan during conservation. In addition, $H$. anomala and $D$. hansenii were found in the fermented fish from Ghana (Sanni et al., 2002) that was similar to the fermented fish of Method 1, whereas the other yeast species had not previously been recovered from the fermented fish products. These results showed that it is advantageous to use this molecular method (PCR-DGGE) to monitor yeasts strains involved in fermented fish by applying it directly to the matrix. The cluster analysis of 26S rDNA banding profiles for yeast 


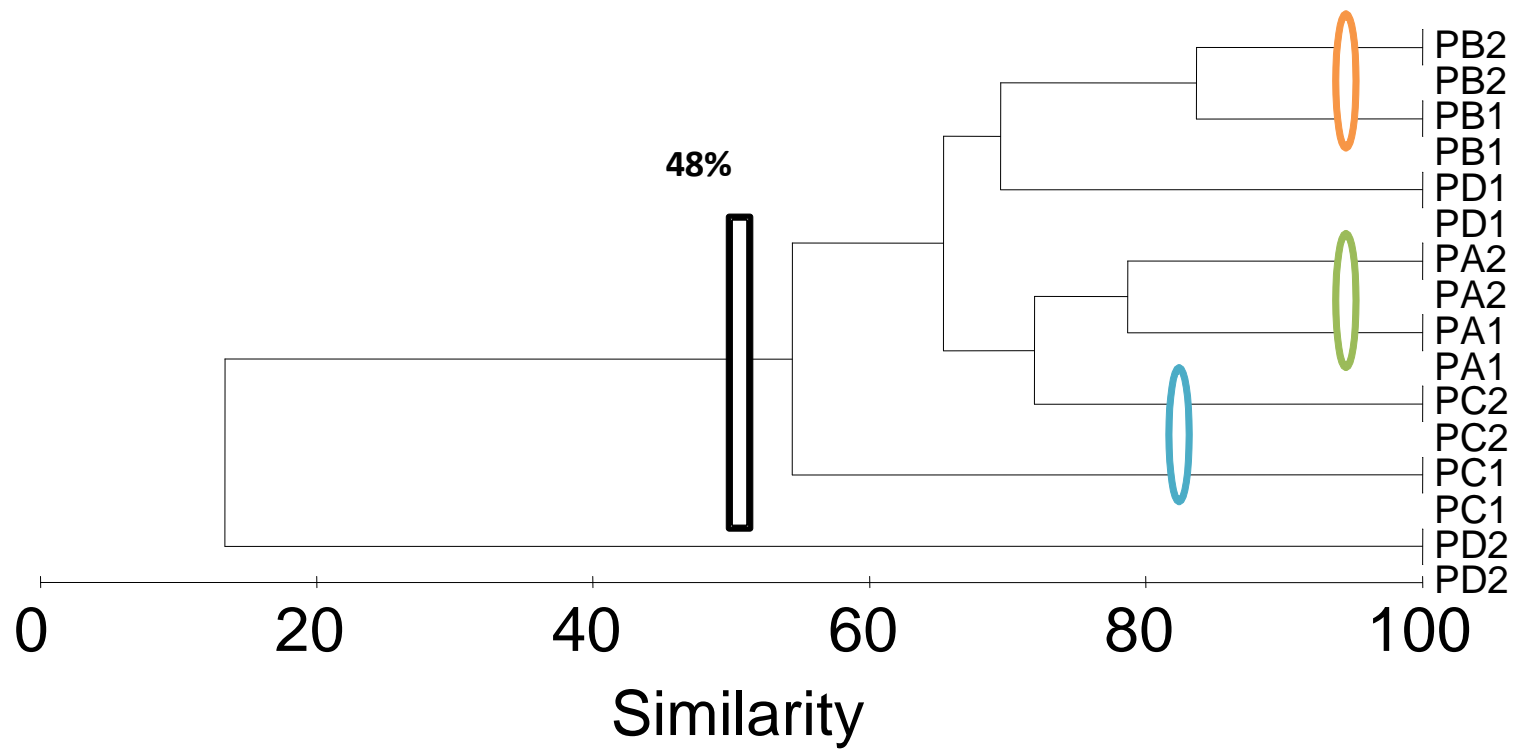

Figure 3. Cluster analysis of $26 \mathrm{~S}$ rDNA banding profiles of yeasts from fermented fish "adjuevan" collected with different producers following two methods of production in Ivory Coast. The acronyms correspond to: Sample of the first and second fermentation respectively of producer A (PA1, PA2) and producer D: (PD1, PD2) from the site of Abidjan-Vridi; producer B (PB1, PB2) and producer C (PC1, PC2) from the site of Assinie. PA1, PA2 and PD1, PD2: Two successive productions carried out by a local producer at Abidjan-Vridi following respectively Method 1 and Method 2 PB1, PB2 and PC1, PC2: Two successive productions carried out by a local producer at Assinie following respectively Method 1 and Method 2.

communities are shown in Figure 3. A strong similarity was observed at $88 \%$ between samples PA1 and PA2, then a similarity of $79 \%$ was observed between samples PB1 and PB2. These statistical treatments confirmed the strong similarity between the samples produced simultaneously using Method 1 by the same producer. However, dissimilarity of $23 \%$ was observed between samples PC1 and PC2 of Method 2, and a higher dissimilarity percentage of $46 \%$ was observed for samples PD1 and PD2. Concerning the origins, no similarity or low similarity was observed between the samples coming from the same origin (Figure 3). Yeast community of the fermented fish was more influenced by the community of the fermentation equipment and the method used. It was also influenced by the community of the original microorganisms of the fish, like the case of the lactic acid bacteria in adjuevan previously reported by Koffi-Nevry et al. (2011).

This study is the first to describe yeasts associated with the Ivorian production of fermented fish by using molecular DGGE method. It is possible that yeasts can be potentially responsible for the flavour of the fish, or some problems encountered by traditional producers while using the two methods of fermentation or conservation. This study, performed by PCR-DGGE, describes the dominant species of yeast in the fermented fish. It could be strengthened by supplementing the DGGE method with analysis based on culture-dependent method to obtain a complete ecology of yeast strains in the fermented fish, Further research could be also done on dominant strains like $D$. Hansenii and $K$. marxianus that could be used as starter cultures for the benefit of the fermented fish, and Ivorian producers.

\section{REFERENCES}

Al-Harbi AH, Uddin N (2003). Quantitative and qualitative studies on bacterial flora of hybrid tilapia (Oreochromis niloticus $\times 0$. aureus) cultured in earthen pond in Saudi Arabia. Aquaculture. 34: 43-48.

Andlid T, Juárez RV, Gustafsson L (1995). Yeast colonizing the intestine of rainbow trout (Salmo gairdneri) and turbot (Scophtalmus maximus). Microbl. Ecol. 30: 321-334.

Andrade MJ, Cordoba JJ, Sanchez B, Casado EM, Rodriguez M (2009). Evaluation and selection of yeasts isolated from dry-cured lberian ham by their volatile compound production. Food Chem. 113: 457463.

Anihouvi VB, Sakyi-Dawson E, Ayernor GS, Hounhouigan JD (2007). Microbiological changes in naturally fermented cassava fish (Pseudotolithus sp.) for lanhouin production. Inter. J. Food Microbiol. 116: 287-291.

Anihouvi VB, Hounhouigan JH, Ayernor SG (2005). Production and marketing of lanhouin, a fermented fish condiment from the Gulf of Benin. Agriculture Book, 14(3): 323-330.

Audigié C, Figarella J, Zonszain F (1980). Manipulation of biochemical analysis. Dion editors, Paris, France.

Betts GD, Linton P, Betteridge RJ (1999). Food spoilage yeasts: effects of $\mathrm{pH}, \mathrm{NaCl}$ and temperature on growth. Food Control. $10: 27-33$.

Bohuon P (1995). Dehydration-impregnation ternary solutions: transportation study of water and gel solutes and products of animal origin. PhD Thesis, University of Montpellier II, Montpellier, France.

Bolumar T, Sanz Y, Flores M, Aristoy MC, Toldra F, Flores J (2006). Sensory improvement of dry-fermented sausages by the addition of cell-free extracts from Debaryomyces hansenii and Lactobacillussakei. Meat Sci. 72: 457-466.

Cocolin L, Manzano M, Cantoni C, Comi G (2000). Development of a 
rapid method for the identification of Lactobacillus spp. isolated from naturally fermented Italian sausage using a polymerase chain reaction-temperature gradient gel electrophoresis. Lett. Appl. Microbiol. 2000:126-129.

Cocolin L, Aggio D, Manzano M, Cantoni C, Comi G (2002). An application of PCR-DGGE analysis to profile the yeast populations in raw milk. Inter. Dairy J. 12: 407-411.

Deak T, Beuchat LR (1996). Handbook of Food Spoilage Yeasts. CRC Press, Boca Raton, Florida, pp. 210.

Dorko E, Komtova M, Pilipcinec E, Bracokova I, Dorko F, Danko J, Svicky E, Tkacikova L (2000). Rare non-albicans Candida species detected in different clinical diagnoses. Folia Microbiol., 45: 364-368.

El Sheikha AF, Condur A, Isabelle Metayer, Le Nguyen DD, Gerard L, Didier M (2009). Determination of fruit origin by using $26 S$ rDNA fingerprinting of yeast communities by PCR-DGGE:preliminary application to Physalis fruits from Egypt. Published online in Wiley InterScience., 26: 567-573.

Fatichenti F, Bergere JL, Deiana P, Farris GA (1983). Antagonistic activity of Debaryomyces hansenii towards Clostridium tyrobutyricum and Clostridium butyricum. J. Dairy Res., 50: 449-457.

Fleet GH (2007). Yeasts in foods and beverages: impact on product quality and safety. Curr. Opin. Biotech., 18: 170-175.

Fleet GH (1990). Yeasts in dairy products. A review. J. Appl Bacteriol., 68: 199-211.

Gatesoupe FJ (2007). Live yeasts in the gut: Natural occurrence, dietary introduction, and their effects on fish health and development. Aquaculture, 267: 20-30.

Heyndrickx MVL, Vandamme P (1996). Applicability of combined amplified ribosomal DNA restriction analysis (ARDRA) patterns in bacterial phylogeny and taxonomy. J. Microbiol Methods, 26: 247259.

Hancock JM, Tautz D, Dover GA (1988). Evolution of the Secondary Structures and Compensatory Mutations of the Ribosomal RNAs of Drosophila melanogaster. Mol. Biol. Evol., 5: 393-414.

Jacques N, Casaregola S (2008). Safety assessment of dairy microorganisms: the hemiascomycetous yeasts. Inter. J. Food Microbiol., 26: 321-326.

Jakobsen M, Narvhus J (1996). Yeasts and their possible beneficial and negative effects on the quality of dairy products. Inter. Diary J., 6: 755-768.

Koffi-Nevry R, Ouina,TS, Koussemon M, Brou K (2011). Chemical composition and lactic microflora of adjuevan, a traditional Ivorian fermented fish condiment. Pakistan J. Nutr., 10: 332-337.

Kowalchuk GA, SJ, De Boer W (1997). Analysis of ammonia-oxidizing bacteria of the $\beta$-subdivision of the class Proteobacteria in coastal sand dunes by denaturing gradient gel electrophoresis and sequencing of PCR amplified 16S ribosomal DNA fragments. Appl. Environ. Microbiol., 63: 1489-1497.

Kurtzman CP, Robnett CJ (1998). Identification and phylogeny of ascomycetous yeasts from analysis of nuclear large subunit (26S) ribosomal DNA partial sequences. Antonie van Leeuwenhoek, 73: 331-371.

Larrouture C, Ardaillon V, Pe'pin M, Montel MC (2000). Ability of meat starter cultures to catabolize leucine and evaluation of the degradation products by using an HPLC method. Food Microbiol., 17: 563-570.

Lücke FK ( 2000). Utilization of microbes to process and preserve meat. Meat Sci., 56: 105-115.

Leesing $R$ (2005). Identification and validation of specific markers for traceability of aquaculture fish for import/export. PhD dissertation, University of Montpellier 2, Montpellier, France.

Lopandic K, Zelger S, Banszky LK, Eliskases-Lechner F, Prillinger H (2006). Identification of yeasts associated with milk products using traditional and molecular techniques. Food Microbiol., 23: 341-350.

Martin A, Cordoba JJ, Aranda E, Cordoba MG, Asensio MA (2006). Contribution of a selected fungal population to the volatile compounds on dry-cured ham. Inter. J. Food Microbiol., 110: 8-18.

Masoud W, Cesar LB, Jespersen L, Jakobsen M (2004). Yeast involved in fermentation of Coffea arabica in East Africa determined by genotyping and by direct denaturating gradient gel electrophoresis. Yeast, 21: 549-556.
Mauriello G, Casaburi A, Blaiotta G, Villani F (2004). Isolation and technological properties of coagulase negative staphylococci from fermented sausages of southern Italy. Meat Sci., 67: 149-158.

Muyzer G, De Waal EC, Uitterlinden AG (1993). Profiling of complex microbial populations by denaturing gradient gel electrophoresis analysis of polymerase chain reaction-amplified genes coding for $16 \mathrm{~S}$ rRNA. Appl. Environ. Microbiol., 59: 695-700.

Muyzer GTA, Wirsen CO, Jannasch HW (1995). Phylogenetic relationships of Thiomicrospira species and their identification in deep-sea hydrothermal vent sample by denaturing gradient gel electrophoresis of 16S rDNA fragment. Archiv. Microbiol., 164: 165172.

Nielsen DS, Teniola OD, Ban-Koffi L, Owusu M, Andersson TS Holzapfel WH (2007). The microbiology of Ghanaian cocoa fermentations analysed using culture dependent and cultureindependent methods. Inter. J. Food Microbiol., 114: 168-186.

Paludan-Muller C, Madsen M, Sophanodora P, Gram L, Peter L M (2002). Fermentation and microflora of plaa-som, a Thai fermented fish product prepared with different salt concentrations. Inter. J. Food Microbiol., 73: 61-70.

Patrignani F, Lucci L, Vallicelli M, Guerzoni ME, Gardini F, Lanciotti R (2007). Role of surface-inoculated Debaryomyces hansenii and Yarrowia lipolytica strains in dried fermented sausage manufacture. Part 1: Evaluation of their effects on microbial evolution, lipolytic. proteolytic. Patterns, 75(4): 676-686.

Pfaller M, Cabezudo I, Koontz F, Bale M, Gingrich R (1987). Predictive value of surveillance cultures for systematic infection due to Candida species. Eur. J. Clin. Microbiol., 6: 628-633.

Pereira-Dias S, Potes ME, Marinho A, Malfeito-Ferreira M, Loureiro V (2000). Characterisation of yeast flora isolated from an artisanal Portuguese ewes cheese. Inter. J. Food Microbiol., 60: 55-63.

Prakitchaiwattana CJ, Fleet GH, Heard GM (2004). Application and evaluation of denaturing gradient gel electrophoresis to analyse the yeast ecology of wine grapes. FEMS Yeast Res., 4: 865-877.

Ramirez-Zavala B, Mercado-Flores Y, Hernandez-Rodriguez C, VillaTanaca $L$ (2004). Purification and characterization of serine carboxypeptidase from Kluyveromyces marxianus. Inter. J. Food Microbiol., 91: 245-252.

Rantsiou K, Cocolin L (2006). New developments in the study of the microbiota of naturally fermented sausages as determined by molecular methods: A review. Inter. J. Food Microbiol., 108: 255-267.

Rantsiou K, Urso R, lacumin L, Cantoni C, Cattaneo P, Comi G, Cocolin $L$ (2005c). Culture dependent and independent methods to investigate the microbial ecology of Italian fermented sausages. Appl. Environ. Microbiol., 71: 1977-1986.

Romano A, Casaregola S, Torre P, Gaillardin C (1996). Use of RAPD and mitochondrial DNA RFLP for typing of Candida zeylanoides and Debaryomyces hansenii yeast strains isolated from cheese. Syst. Appl Microbiol., 19: 255-264.

Ros-Chumillas M, Egea-Cortines M, Lopez-Gomez A, Weiss J (2007). Evaluation of a rapid DNA extraction method to detect yeast cells by PCR in orange juice. Food Control, 18: 33-39.

Sanni Al, Asieduw M, Ayernorw GS (2002). Microflora and Chemical Composition of Momoni, a Ghanaian Fermented Fish Condiment Department of Botany and Microbiology, University of Ibadan, Nigeria; and Department of Nutrition and Food Science, University of Ghana, Legion, Ghana. J. Food Comp. Anal., 15: 577-583.

Van Hannen EJ, Zwart G, Van Agterveld P, Gons HJ, Ebert J, Laanbroek HJ (1999). Changes in bacterial and eukaryotic community structure after mass lysis of filamentous cyanobacteria associated with viruses. Appl. Environ Microbiol., 65: 795-801.

Viljoen BC, Greyling T (1995). Yeasts associated with Cheddar and Gouda making. Inter. J. Food Microbiol., 28: 79-88.

Vázquez-Juárez R, Andlid T, Gustafsson L, Wadström T (1993). The expression of potential colonization factors of yeasts isolated from fish during different growth conditions. Can. J. Microbiol., 39: 11351141. 